\title{
Occupational emerging risks affecting international virtual project team results
}

\author{
Iulia Dumitraşcu-Băldău1, ${ }^{1,}$, and Dănuţ Dumitru Dumitraşcu ${ }^{2}$ \\ 1 Lucian Blaga University of Sibiu, Department of Management, Calea Dumbravii 17, Sibiu, \\ Romania \\ ${ }^{2}$ Lucian Blaga University of Sibiu, Department of Industrial Engineering and Management, Emil \\ Cioran 4, Sibiu, Romania
}

\begin{abstract}
The expansion of internet access, high-speed connection services, collaborative work platforms and tools, allowed employees to interact virtually offering companies the possibility to develop projects around the world, reducing operational costs and gain competitive advantage. Realizing the advantages and disadvantages of developing a project team in an international virtual work environment, requires adopting specific strategies to construct an effective team and ensure the project success. One of the most important disadvantages that we identified is that the new work environment brings new risks for both team members and managers. So, it becomes mandatory to identify and analyze the occupational emerging risks and their impact on the productivity of virtual team members, in order to prevent them efficiently and to ensure the safety and health of employees in a virtual working environment. This paper aims to highlight the necessity for project managers and organizations, to include in their specific project strategies, an efficient occupational risks management in the virtual workplace, to obtain a continuously improved virtual working environment, so to achieve a high performance from virtual employees.
\end{abstract}

\section{Introduction}

If until the advent of the Internet, outsourced collocated project teams, were communicating by phone, fax, or through numerous face-to-face extremely expensive meetings, subsequently the Internet has enabled a substantial reduction of these costs and even their elimination, transforming these dispersed teams into virtual project teams, allowing organizations to convert technology into a competitive advantage. "Organizations around the world are increasingly involving in projects developed across borders, building virtual teams, given the many advantages they offer" [1]. "Many companies will be less concerned with their internal capabilities and more focused on the value they can draw from external networks" [2]. Companies can use virtual project teams also to align environmental protection agreements, because these teams can gain the title of "green job" taking into account that one of their advantages is to reduce the carbon footprint [3], what emerges

*Corresponding author: iulia.dumitrascu@ulbsibiu.ro 
indirectly from the definition of the virtual team: "a virtual team is one that does much of its work across distances facilitated by technology, as opposed to doing much of its work face-to-face contexts"[4]. 2020 EU Strategy [5] proposes three priorities, among which the first two, are in perfect accordance with the definition of the virtual teams. European Commission defines green jobs as "covering all jobs that depend on the environment or are created, substituted or redefined (in terms of skills sets, work methods, profiles greened, etc.) in the transition process towards a greener economy" [6]. European Agency for Safety and Health at Work (EU-OSHA) considers that "green jobs can be understood as contributing, in some way, to the preservation or restoration of the environment" [7]. These 'green-jobs' definitions, can be identified to some extent with the work in virtual environment or, with international virtual project teams.

\section{Defining the problem}

The emergence of virtual work environment, following the development of information and communication technology, has also led to the emergence of new occupational health and safety risks-OSH. "The new and emerging OSH, may have different origins, in particular: new technologies, new production processes, new forms of work and emerging forms of work" [8]. "ICT-related changes in the world of work, more so than the technology itself, brings about not only great opportunities but also a number of health and safety risks"[9]. Considering the importance that EU-OSHA is giving to "green-jobs" having dedicated a special section within emerging risks on the website [7], the present information regarding the virtual working environment and the risks involved, is very scarce in the literature and is not taken into account in the studies undertaken so far by EU-OSHA. Instead, we identified that there is an interest in studying them, in the future [10].

\section{Hypothesis}

We believe that identifying these risks can assist project managers in establishing effective strategies for preventing them, so the results of international virtual project teams, will not be affected. The European Parliament noted that globalization has negative effects on safety and fairness at work [11]. The best way to deal with these risks is the prevention, and the virtual team members' preparation in this respect is fundamental, given that they work remotely. Awareness of these risks and their severity by employees through specific trainings, setting rules and making available the necessary tools to work in the virtual environment, are some of the responsibilities of the manager and the organization that is creating such project teams. "Glover predicts big changes in the way that companies are organised, with less focus on developing internal capabilities among their own workforces and more on bringing together capabilities from a number of different sources, such as consultants and freelancers, in a virtual workplace" [2]. "It is likely to be hard to assess OSH risks consistently and regularly for mobile or remote workers. They may suffer from a lack of OSH monitoring and a poorer access to OSH services. A virtual workforce could find it difficult to know that OSH information and services relevant to them exists and it could also be very difficult for OSH regulators to influence such a workforce" [12].

\section{Emerging risks affecting international virtual project team results}

EU-OSHA defined emerging occupational risks as "any new and growing occupational risk" [13]. "Currently, the attention focuses on lesser-known risks, which are interpreted as 
emerging, although some of these were present before. They acquire their emerging nature due to one of the following conditions: the risks are better measured, quantified and evaluated or the society is sensitizing to the nature and potential consequences of those risks" [14]. "In 2002, EU- OSHA has set up a "Risk Observatory". There were identified and considered four different types of risks, to provide a more complete view of the work: a) physical risks; b) organizational, social and human risks; c) biological risks; d) chemical risks, without excluding multifactorial risks that may be identified in several of the categories mentioned"'[15].

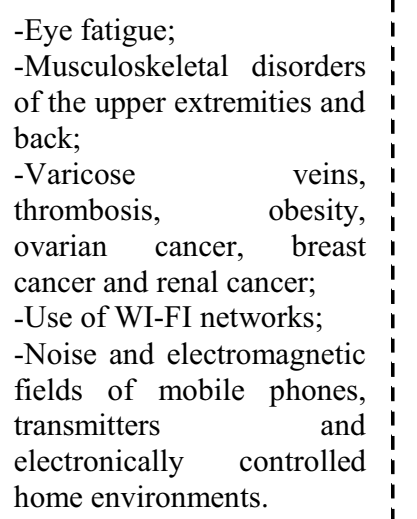

veins, I

obesity, I

reast !

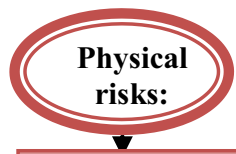

I

I

\section{I}

I

between different

national cultures, especially,

the existence of other

differences such as language,

ethical, educational, etc., team members' isolation, inadequate

distribution of project tasks.
Psychosocial risks
-The absence of controlled ultraviolet light exposure: insomnia and lack of vitamin D, which can cause various physical disorders: bone pain, muscle weakness, diabetes, cardiovascular disease, cognitive disorders, asthma, and cancer.

Lower level of productivity for international virtual project team

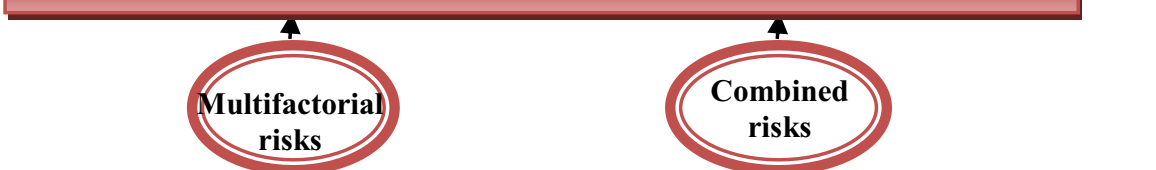

\section{Other}

risks

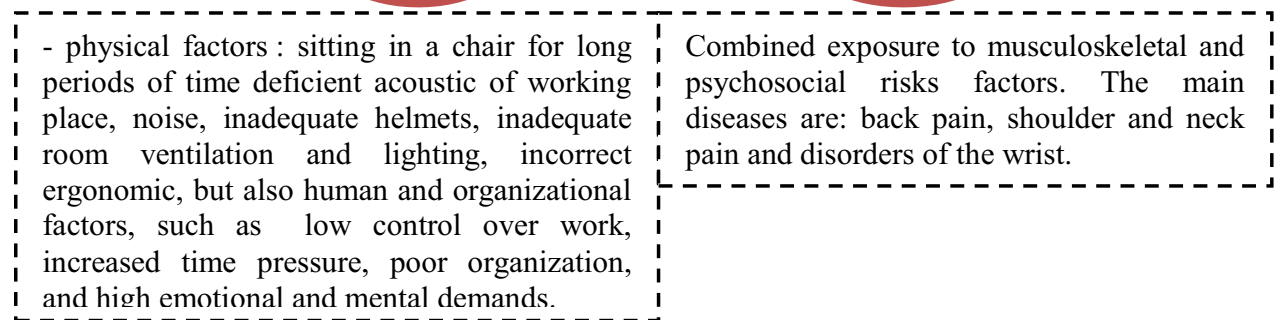

Fig. 1. Emerging risks affecting international virtual project team productivity.

We identified a number of risks, which can be assimilated to virtual work environment, establishing a link between office work risks, removing the ones related to the physical presence of the other team members, and adding the risks generated by the lack of their presence, the risks related to the work from home, those specific to teleoperator's work, or those related to visual display unit users. In addition to these risks in the literature, we 
propose specific risks for the international working environment. We've created Figure 1, in order to offer a schematic vision of these risks.

Given that virtual project team members communicate via technology-driven tools, they spend most of their time in front of a digital screen, which causes eye fatigue or accommodative asthenopia. The "lack of physical activity at work, involve both, sitting, or standing for long periods of time"[15]. "An increase in the use of computers and in productivity demands leads to more time spent in a fixed body posture"[16]. The widespread use of non-ergonomic mobile devices such as smart phones, tablets, laptops, can also lead to worsening musculoskeletal disorders. "Global mobile data traffic grew 63 percent in 2016. Global mobile devices and connections in 2016 grew to 8.0 billion, up from 7.6 billion in 2015. Of all IP traffic (fixed and mobile) in 2021, 50\% will be Wi-Fi, $30 \%$ will be wired, and $20 \%$ will be mobile" [17]. Studies also suggest the need for a better understanding of the physical risks regarding noise and electromagnetic fields of mobile phones, transmitters and electronically controlled home environments [18]. Psychosocial risks identified in the literature [15], including those identified by EU- OSH [16] are mentioned in Figure 4.1. Addressing psychosocial risks in terms of poor mental health, presents additional challenges due to the complexity in measuring and assessing causation of mental disorders [19]. There are different theoretical models of psychosocial risks and their effects, and the best known is the model of R.A. Karasek [20], demand-control. This model identifies two psychosocial risks: high demands at work and poor control activity at work. This control activity relates primarily to the possibility of choosing tasks, how to do the tasks to achieve the desired results, working time and breaks. "This is particularly important to meet the demands of the workplace involving a high volume, fast pace and deadlines" [19]. "Common mental disorders such as depression and anxiety are the results of most epidemiological evidence available regarding decreased control over the activity at work" [20]. In terms of job security within international projects, it has a degree quite low, because contracts are signed for a limited period of time, during the project. "Workers employed based on insecure and flexible contracts with unpredictable hours and workload, are more prone to occupational diseases" [21]. Whittaker thinks it is possible that we will see a continuation of recent trends towards increased self-employment and use of nonstandard employee contracts, including temporary working [2]. Also, into psychosocial risks category may be included the "technostress", which can occur when the employees experience regarding IT failures is not able to produce improvements or to face pressures produced by performance monitoring through technology [23]. This type of stress is specific to virtual international project teams, given the need of continuous improvement and adapting skills to the needs of the project, the technology used and also to the sheer volume of information. "Since ICT has the ability to allow a 24/7 economy, this can lead to stress during the work time, and experts have expressed their concern indicating that the widespread use of hand devices, such as smart phones, tablets, could lead to an imbalance between private and professional life, working hours in excess and insufficient time to relax" [24]. "It becomes increasingly difficult to achieve a good work-life balance due, in part, to work pressure but also driven by the "fear of missing out' syndrome" [25]. "The use of computers and smart phones with internet which provides easy access to all kinds of information but also the expectation from colleagues, supervisor and clients that one is always available, always reads e-mails and can always be contacted. Technology has a great impact on workers' task characteristics and hence on their health and well-being" [16]. As a result of excessive working time, we can add the risk that those employees may recourse to the use of drugs to enhance performance in work. In international projects, the high level of diversity, can cause communication difficulties, distrust, conflict, team members isolation, inadequate distribution of tasks and their lack of synchronization with time project, all leading to mental disorders such as depression and anxiety. Regarding 
combined risks, "it has been shown that exposure to musculoskeletal risks combined with psychosocial ones, affect workers at a greater extent than when taken separately" [26]. Concerning, multifactorial risks, the main problems observed are: musculoskeletal disorders, varicose veins, nose and throat diseases, voice disorders, fatigue, and stress" [27]. Also, if in the literature we find the exposure to ultraviolet radiation as a physical risk, we can mention that doctors consider the absence of controlled ultraviolet light exposure, as being an important risk, due to the disturbance of the circadian rhythm, which may lead to insomnia and also the lack of vitamin $\mathrm{D}$, which can cause various physical disorders. This is caused by long hours in an office with limited or no access to sunlight.

\section{Risk Assessment for virtual teams in international projects, using OiRA tool}

"If risks are not assessed or properly dealt with, a suitable risk management process cannot be started and appropriate preventive measures are unlikely to be found or put in place"[28]. "What's more, case studies show that good OSH management in a business is linked to improved performance and profitability. Not only does poor safety and health cost companies money, but good OSH pays dividends. Businesses with higher safety and health standards are more successful and sustainable" [29]. "Studies estimate that for every euro invested in $\mathrm{OSH}$, there is a return of 2.2 Euros and that the cost-benefit ratio of improving safety and health is favourable. The economic advantages of good OSH for businesses large and small are significant. To give just a few examples, good workplace safety and health: Improves workers' productivity, Cuts down on absenteeism, Reduces compensation payments, Meets the requirements of public and private sector contractors" [29].

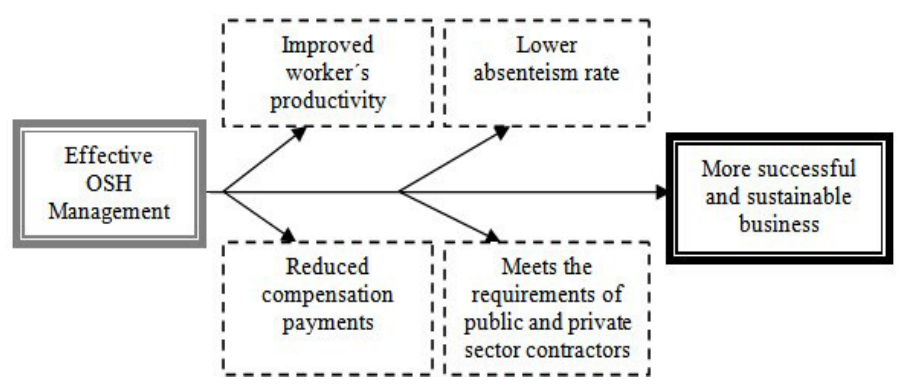

Fig. 2. Effective OSH Management Results.

We used OiRA instrument - Online interactive Risk Assessment, to assess risks in a virtual environment in international projects. OiRA is a web platform that enables the creation of sector risk assessment tools in different languages in a standardised way, developed and maintained by EU-OSHA and it is based on the Dutch risk assessment instrument RI\&E [30]. There is no specific tool in Romanian or specific to Romania. As an activity sector or workplace, ICT or virtual work environment is not found in the default list. For which we used the generic tool in English. This risk assessment tool is mainly intended for micro (less than 10 workers) and small (less than 50 workers) enterprises/organisations, which corresponds to the virtual project team ideal size [31].

OiRA generic tool includes 11 categories of risks, of which we excluded 3 of them: dangerous substances; machine safety; personal protective equipment and health and safety signs, considering they are not appropriate for the virtual work environment. Following the risk assessment, we created Table 5.2, where we included all the identified risks due to the expertise on international virtual working environment. The priority of the risk is calculated 
by the system, according the answers given regarding the probability of the risk occurring, how often are the workers exposed to that risk and the severity of the damage.

Table 5.2. OSH risk assessment for virtual teams in international projects, using OiRA tool.

\begin{tabular}{|c|c|c|}
\hline $\mathrm{N}^{0}$ & Category & Risks \\
\hline 1 & $\begin{array}{l}\text { Help with in- } \\
\text { house } \\
\text { emergencies }\end{array}$ & $\begin{array}{l}7 \text { Present Risks: } 7 \text { Low priority risks: - It's possible that it's not clear for some } \\
\text { workers what to do in case of emergencies. • No special training has been } \\
\text { provided for in-house emergency officers with regard to special risks. } \\
\text { Emergency equipment and resources laid down in the emergency planning is not } \\
\text { or might not be sufficient. - An in-house emergency plan doesn't exist. - There } \\
\text { is no written document on the duties of in-house emergency officers. • In-house } \\
\text { emergency officers did not receive adequate training. - There are no or not } \\
\text { enough in-house emergency officers. }\end{array}$ \\
\hline 2 & $\begin{array}{l}\text { Organization } \\
\text { workplaces }\end{array}$ & $\begin{array}{l}13 \text { Present Risks: } 5 \text { High priority risks: } \bullet \text { No area for relaxation (canteen or other } \\
\text { catering area) separated from the workplace is provided. } \bullet \text { There are places where } \\
\text { work is conducted and smoking is allowed or where tobacco smoke enters } \\
\text { working areas. } \bullet \text { Some equipment in the enterprise might be connected to } \\
\text { extension cords and/or might not have a residual current operated circuit-breaker } \\
\text { being tested at least once a quarter. } \bullet \text { The enterprise's electrical installation is not } \\
\text { inspected regularly. Inspection intervals of } 5 \text { years are sometimes not respected. } \\
\text { Work on the electrical systems including first connection of machinery and } \\
\text { equipment is not always performed by a competent person. } 2 \text { Medium priority } \\
\text { risks: } \bullet \text { Toilets, urinals, washbasins and changing rooms are not cleaned daily. } \\
\text { It's not well or not at all indicated where fire prohibitions apply. } \\
6 \text { Low priority risks: } \bullet \text { Entrance doors are not periodically maintained and } \\
\text { inspected (annually). } \text { - Not all fire extinguishing facilities are inspected } \\
\text { regularly. The required fire extinguishing facilities are not always present, } \\
\text { recognisable and accessible in all areas. There are no maps indicating where a } \\
\text { person is and which escape routes can be used. } \bullet \text { Not all emergency exits are } \\
\text { clearly indicated and accessible. Emergency exits might not be adequate. }\end{array}$ \\
\hline 3 & $\begin{array}{c}\text { Physical } \\
\text { stress and } \\
\text { visual } \\
\text { display unit } \\
\text { work }\end{array}$ & 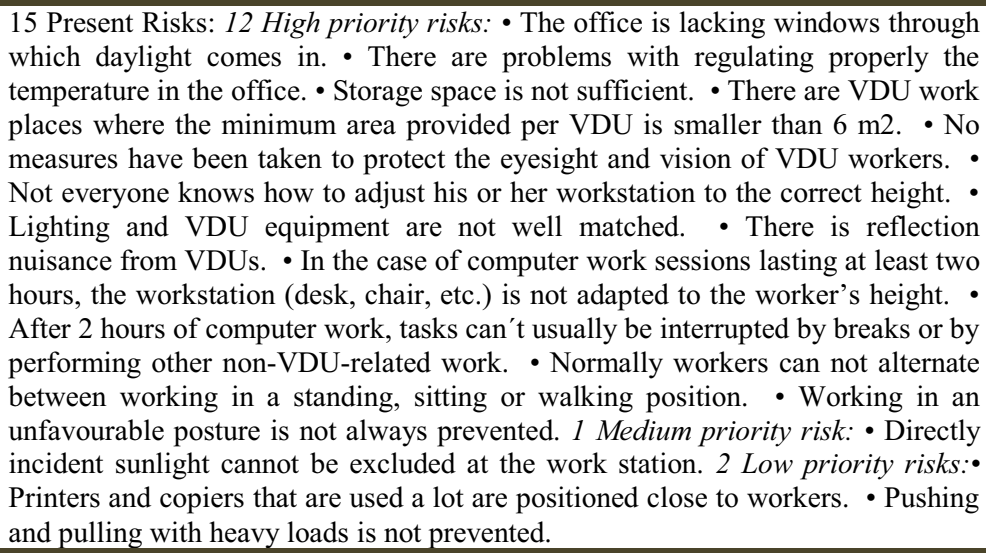 \\
\hline 4 & $\begin{array}{c}\text { Undesirable } \\
\text { behaviours } \\
\text { and work } \\
\text { pressure }\end{array}$ & $\begin{array}{l}9 \text { Present Risks: } 5 \text { High priority risks: } \bullet \text { Working overtime is regularly occurring. } \\
\text { - Resources needed for work are not always available in time and/or do not work } \\
\text { well. - Tasks are not evenly distributed in all functions. - With regard to } \\
\text { functions in your enterprise there is an imbalance concerning work rate, work } \\
\text { supply and time pressure. - There is no special training for employees with } \\
\text { contact with customers/patients/ visitors on how to deal with undesirable } \\
\text { behaviour. } 4 \text { Low priority risks: }{ }^{\bullet} \text { There is no formal complaints procedure for } \\
\text { employees who want to report undesirable behaviour. - There is no confidential } \\
\text { adviser employees can appeal to in case of problems. - No attention is paid on } \\
\text { prevention of undesirable behaviour. - There are no arrangements concerning } \\
\text { undesirable behaviour between employees. }\end{array}$ \\
\hline 5 & Working & $\begin{array}{l}2 \text { Present Risks: } 2 \text { High priority risks: }{ }^{-} \text {The same rules apply to all employees, no } \\
\text { differences are made for pregnant women and employees who gave birth. }\end{array}$ \\
\hline
\end{tabular}




\begin{tabular}{|c|c|c|}
\hline & $\begin{array}{l}\text { hours and } \\
\text { rest periods }\end{array}$ & Agreements concerning on-call services are vague and/or don't follow clear rules. \\
\hline 6 & $\begin{array}{l}\text { Environmen } \\
\text { tal factors }\end{array}$ & $\begin{array}{l}4 \text { Present Risks: } 3 \text { High priority risks: - The amount of (day) light in the } \\
\text { workplaces is not always adequate and/or incoming sunlight sometimes cannot be } \\
\text { shaded. - There is inadequate ventilation in the space. - The temperature at the } \\
\text { workplace might be suboptimal; workers are dissatisfied with the temperature. } 1 \\
\text { Low priority risk: - There are workplaces where draughts occur. }\end{array}$ \\
\hline 7 & $\begin{array}{l}\text { Occupationa } \\
1 \text { health care } \\
\text { and } \\
\text { organization } \\
\text { of work }\end{array}$ &  \\
\hline 8 & $\begin{array}{l}\text { Additional } \\
\text { risks }\end{array}$ & $\begin{array}{l}4 \text { Present Risks: } 4 \text { High priority risks : } \bullet \text { Job insecurity } \bullet \text { Tehnostress } \bullet \text { Interaction } \\
\text { between different national cultures. } \bullet \text { Lack of direct sun exposure. }\end{array}$ \\
\hline
\end{tabular}

\section{Conclusions and future lines of research}

Following the bibliographic study and using the OiRA risk assessment instrument, we believe that the main risks that may affect, in a significant way, the international project team members performance in the virtual environment, are the psychosocial risks, and stress being one of the most complex phenomena needed to be studied and analyzed in accordance with the characteristics of virtual work environment and international project.

While recognizing the role of individual dispositions and the overall life circumstances, it has been demonstrated that stress caused by work-related factors can significantly affect the employees' proper functioning both within work and outside. Its symptoms include emotional problems (irritability, becoming solitary, feeling exhausted), cognitive (difficulty concentrating and making decisions, negative thinking) and behavioural (negligence, abuse of alcohol, drugs, medication) [32]. Great Britain's Health and Safety Executive, estimated that in $2015 / 2016$, the total number of lost working days due to work-related stress, anxiety 
and depression was 11.7 million days, an average of 23.9 days lost in each case [33]. Absenteeism and poor performance attract significant economic implications. The total cost of psychosocial risks and stress related to work activity, for business and society as a whole- including health care, disability, early retirement, low productivity, high staff turnover and other direct and indirect expenses- is estimated at several billions [32].

Given the implications of the emerging occupational risks' effects, it becomes clear that is needed more information and tools adapted to virtual work environment to assess and achieve an effective risk management. The main contributions of this paper are represented in the following figures: Figure 1. Emerging risks affecting international virtual project team productivity; Figure 2. Effective OSH Management Results; Table 5.2. OSH risk assessment for virtual teams in international projects, using OiRA tool. Also, this paper may represent a starting point in conducting an empirical research on emerging risks in virtual international project teams, in order to validate the identified risks, and based on that, it can be developed a specific tool for the virtual work environment in international projects, using OiRA generator tool. Also, it can be used a multi-criteria analysis used in the integration process of the organizations [34], to the virtual environment, in order to take efficient risk management decisions.

\section{References}

1. K. Fisher, M. Fisher, Manager's guide to Virtual Teams, $1^{\text {st }}$ edition (McGraw-Hill Education, Madison, Wisconsin, 2011).

2. Institute for Public Policy Research, Technology, globalization and the future of work in Europe, (2017).

3. Dumitraşcu, D.D. Dumitraşcu, Revista de Management și Inginerie Economică, 14 (4), 691701(2015).

4. P.E. Brewer, International Virtual Teams: Engineering Global Success (IEEE PCS Professional Engineering Communication Series, Wiley-IEEE Press, 2015).

5. European Commission, Communication from the Commission Europe 2020-A strategy for smart, sustainable and inclusive growth (Available at:

http://ec.europa.eu/eu2020/pdf/COMPLET\%20EN\%20BARROSO\%20\%20\%20007\%20\%20Europe\%202020\%20-\%20EN\%20version.pdf, 2010)

6. European Commission, Commission staff working document - Exploiting the employment potential of green growth, (Available at:

https://www.google.ro/url?sa=t\&rct=j\&q=\&esrc=s\&source=web\&cd=1\&cad=rja\&uact=8\&ved $=0$ ahUKEwiRuIaQ2oPUAhXpFZoKHXNnAp8QFggkMAA\&url=http\%3A\%2F\%2Fwww.cede fop.europa.eu\%2Ffiles\%2FSWD_green-growth_EN.pdf\&usg=AFQjCNGde1gxl-

fshwTknZRSoyxPdqLamQ, 2012)

7. $\quad * * *$ https://osha.europa.eu/en/emerging-risks/green-jobs, Accesed: martie 2017

8. $* * *$ https://oshwiki.eu/wiki/OSH in general, Accesed: martie 2017

9. C. Degryse, Digitalisation of the economy and its impact on labour markets (Working Paper. ETUI aisbl, Brussels, 2016).

10. N. Stacey, S. Bradbrook, J. Reynolds, and H. Williams, Review of drivers and trends of change in information and communication technologies and work location, (Available at: https://oshwiki.eu/images/f/ff/Summary_report_Key_trends_and_drivers_of_change.pdf, 2016).

11. European Commission, EU Employment and Social Situation: Quarterly Review (European Commission, Brussels, 2013).

12. Ministry of Social Affairs and Health Finland, Global health security agenda pilot assessment of the United Kingdom, (Available at:

https://www.gov.uk/government/uploads/system/uploads/attachment_data/file/456984/Independ entReport_GHS_acc.pdf, 2015).

13. EU-OSHA, Topic Centre Risk Observatory, European Risk Observatory Report, Luxembourg: Office for Official Publications of the European Communities, (2007). 
14. L. I. Cioca, R. I. Moraru, Managementul Riscurilor profesionale psihosociale, (Editura Universitatii "Lucian Blaga" din Sibiu, 2010).

15. D. Reinert, E. Flapsoler, A. Hauke, E. Brun, Safety Science Monitor, 11 (3), 1 - 17, (2007).

16. $* * *$ https://oshwiki.eu/wiki/Monitoring_new_and_emerging_risks

17. $* * *$ Cisco Visual Networking Index: Global Mobile Data Traffic Forecast Update, 2016-2021 White Paper, (Available at: http://www.cisco.com/c/en/us/solutions/collateral/serviceprovider/visual-networking-index-vni/mobile-white-paper-c11-520862.html, 2017).

18. European Agency for Safety and Health at Work - EU-OSHA, Scoping study for a foresight on new and emerging occupational safety and health $(\mathrm{OSH})$ risks and challenges, Luxembourg: Publications Office of the European Union, (2014).

19. Kyaw-Myint, Su Mon, L. Strazdins, M. Clements, P. Butterworth, L. Gallagher, Safety Science 93, $143-151,2017$.

20. R. A., Jr. Karasek, Administrative Science Quarterly, 24 (2), 285-308 (1979),

21. N. Clumeck, C. Kempenaers, I. Godin, M. Dramaix, M. Kornitzer, P. Linkowski, F. Kittel,. Community Health 63 (4), 286-292, (2009).

22. ILO 'XIX World Congress on Safety and Health at Work - Global trends and challenges' (ILO, Geneva), (2011).

23. Dewe and Kompier, Foresight Mental Capital and Wellbeing Project. Wellbeing and work: Future challenges, The Government Office for Science, London, (2008).

24. European Agency for Safety and Health at Work, EU-OSHA Multi-Annual Strategic Programme (MSP) 2014-2020, EU-OSHA, Bilbao, (2013).

25. N. Stacey, S. Bradbrook, J. Reynolds, and H. Williams, Review of drivers and trends of change in information and communication technologies and work location, (Available at: https://oshwiki.eu/images/f/ff/Summary_report_Key_trends_and_drivers_of_change.pdf, 2016).

26. R.H. Westgaard, 31 (6), 569-580, (2000).

27. J. Cramer, R.P. Ellegast, T. von der Heyden,M. Liedtke, W.Pfeiffer, R. Stamm, Arbeitsumgebung und Ergonomie. (Call Report 4. Hrsg: Verwaltungs-Berufsgenossenschaft, Hamburg, 2001).

28. $* * *$ https://client.oiraproject.eu/nl/generic/generic-tool-in-english/start

29. D. Bräunig, T. Kohstall, Calculating the international return on prevention for companies Final report (Available at: http://publikationen.dguv.deldguv/pdf/10002/23_05_report_2013-en-web-doppelseite.pdf, 2013).

30. $* * *$ https://oiraproject.eu/en/what-oira

31. K. Ferrazzi, Getting Virtual Teams Right, (Available at: https://hbr.org/2014/12/getting-virtualteams-right, 2014.)

32. European Agency for Safety and Health at Work, Second European Survey of Enterprises on New and Emerging Risks (ESENER-2) Overview Report: Managing Safety and Health at Work, European Risk Observatory, Luxembourg: Publications Office of the European Union, (2016).

33. HSE, Work related stress, anxiety and depression statistics in Great Britain, (Available at: http://www.hse.gov.uk/statistics/causdis/stress/stress.pdf, 2016).

34. M. Cioca, L.I. Cioca, L. Duţă, Studies in Informatics and Control, 20 (2), 129-134, (2011). 